\title{
Cytotoxic and Anti-Tumour Promoting Activities of Carbazole Alkaloids from Malayan Murraya koenigii (L.) Spreng
}

\author{
Kartini Ahmad ${ }^{*}$, Siow-Ping Tan', Mohd Aspollah Sukari², Abdul Manaf Ali2,3, \\ Mohd Azlan Nafiah ${ }^{1}$ \\ ${ }^{1}$ Department of Chemistry, Faculty Science and Mathematics, University Sultan Idris, Tanjong Malim, \\ Malaysia \\ ${ }^{2}$ Department of Chemistry, Faculty Science, University Putra Malaysia, Serdang, Malaysia \\ ${ }^{3}$ School of Biotechnology, Faculty of Agriculture, Biotechnology \& Food Science, University Sultan Zainal Abidin, \\ Kuala Terengganu, Malaysia \\ Email: ${ }^{*}$ kartini@fsmt.upsi.edu.my
}

Received 1 July 2014; revised 3 August 2014; accepted 22 August 2014

Copyright (C) 2014 by authors and Scientific Research Publishing Inc.

This work is licensed under the Creative Commons Attribution International License (CC BY).

http://creativecommons.org/licenses/by/4.0/

(c) (i) Open Access

\begin{abstract}
Murraya koenigii (L.) (Rutaceae) is an indigenous medicinally important herb of Indian origin and now is widely distributed throughout southern Asia. The stem bark, leaves and roots of Malayan Murraya koenigii were selected for phytochemical investigation. Eight carbazole alkaloids was isolated and identified using spectroscopic methods including NMR, IR, UV, MS spectra data. Crude extract and isolated compounds from the roots of this plant were screened for cytotoxic activity and antitumor promoting activity. All crude extracts of the roots including the isolated compounds, mahanimbine, mahanine and murrayafoline-A exhibited significant cytotoxic activity against CEM-SS cell line with $\mathrm{IC}_{50} 3 \mu \mathrm{g} / \mathrm{mL}$. Girinimbine inhibited EBV-activation in the antitumor promoting assay.
\end{abstract}

\section{Keywords}

Carbazole, Rutaceae, Murraya koenigii, NMR, Cytotoxic

\footnotetext{
"Corresponding author.
} 


\section{Introduction}

Murraya koenigii is a member of Rutaceae family and represented by about 150 genera and 1600 species. 14 species of this genus are known [1], but only two species can be found in Malaysia; namely Murraya koenigii and Murraya paniculata [2] [3]. Murraya koenigii is a medicinal important herb of Indian origin. It has been widely used as natural flavouring in curries and sources [3]-[5], and ingredient in traditional medicine formulations [4]-[6]. It has also reported by researchers that carbazole alkaloids possess various biological activities such as antitumor, anti-oxidative, anti-mutagenic, and anti-inflammatory activities [6]-[8].

The aim of the present study was to examine the cytotoxic potential and antitumor promoting activity of crude extract and the isolated carbazole alkaloids present in M. koenigii. In our continuing study on leaves, roots and barks of M. koenigii (L.) Spreng, have afforded eight carbazole alkaloids; from bark: mahanimbine 1, girinimbine 2, murrayacine 3, murrayazoline 4 and murrayanine 5; from leaves: mahanimbine $\mathbf{1}$ and mahanine $\mathbf{6}$; and from roots: girinimbine 2 murrayanine 5, 3-methylcarbazole 7 and murrayafoline-A 8. Their structures were elucidated by combination of various spectroscopic methods such as 1D and 2D NMR, IR, UV and MS.

\section{Experimental}

\subsection{General Experimental Procedures}

Spectra were recorded on the following instruments. The IR spectra were recorded using $\mathrm{KBr}$ disc on Perkin Elmer FTIR Spectrophotometer model 1650. UV spectra were recorded on a Shimadzu UV-2100 spectrophotometer. ${ }^{1} \mathrm{H}$ and ${ }^{13} \mathrm{C}$ NMR spectra were obtained on JEOL Spectrometer at $500 \mathrm{MHz}$ with tetramethylsilane (TMS) as the internal standard. Mass spectra were recorded on an AEI-MS 12 instrument. The column chromatography was carried on silica gel (Merck 9385) and Merck silica gel $60 \mathrm{PF}_{254}$ was used for analytical TLC analysis. Analytical Thin Layer Chromatograph (TLC) was performed on commercially available Merck DC-Plasticfolien TLC plastic sheet precoated witih Keiselgel $60 \mathrm{P}_{254}$.

\subsection{Plant Material}

The barks, leaves and roots of Murraya koenigii for this study were collected in Banting, Selangor, Malaysia in 1996.

\subsection{Extraction and Isolation}

The dried bark (1.1 kg) of Murraya koenigii were ground into find powder and extracted continuously soaking for three days with petroluem ether, chloroform and methanol. Each extraction was repeated three times. Then the extract was dried on the rotary evaporator. After removal of the solvents, the crude of petroluem ether (42.2 $\mathrm{g}$ ), chloroform (40.5 g) and methanol (40.0 g) were obtained. After evaporation of the solvent, $15.0 \mathrm{~g}$ of the petroluem ether crude was subjected to column chromatography over silica gel (gradient solvent system; Petroluem ether, $\mathrm{CHCl}_{3}$ and $\mathrm{MeOH}$ ) yielded five known compounds: mahanimbine (1, $\left.60.1 \mathrm{mg}\right)$, girinimbine (2, 70.2 $\mathrm{mg})$, murrayacine $(\mathbf{3}, 4.5 \mathrm{mg})$, murrayazoline $(\mathbf{4}, 6.3 \mathrm{mg})$ and murrayanine $(\mathbf{5}, 9.9 \mathrm{mg})$.

The dried leaves (600 g) of Murraya koenigii were ground and extracted exhaustively with petroluem ether followed by chloroform and methanol by soxhlet extractor for 17 hours. After evaporation of the solvent, $16.8 \mathrm{~g}$, $11.2 \mathrm{~g}$ and $15.8 \mathrm{~g}$ of crude extracts, respectively, were obtained. $15.0 \mathrm{~g}$ of petoluem ether crude was subjected to column chromatography over silica gel (gradient solvent system; petroluem ether, chloroform and Methanol) yielded mahanimbine (1, $0.21 \mathrm{~g}) .10 .0 \mathrm{~g}$ of chloroform crude was subjected over silica gel and yielded mahanine (6, $13.1 \mathrm{mg})$.

The air-dried and finely grounded roots $(1.1 \mathrm{~kg})$ of Murraya koenigii were extracted with petroluem ether and methanol for 48 hours for three times. After evaporation of the solvent, $10.0 \mathrm{~g}$ of petoluem ether crude was subjected to column chromatography over silica gel (gradient solvent system; petroluem ether, chlorofom and Methanol) yielded four carbazoles: girinimbine (2, $0.21 \mathrm{~g})$, murrayanine (5, $30.2 \mathrm{mg})$, 3-methylcarbazole (7, $8.3 \mathrm{mg})$ and murrayafoline-A (8, $0.10 \mathrm{~g})$. 

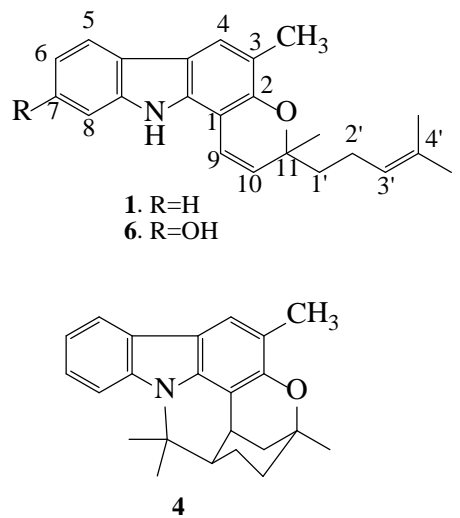

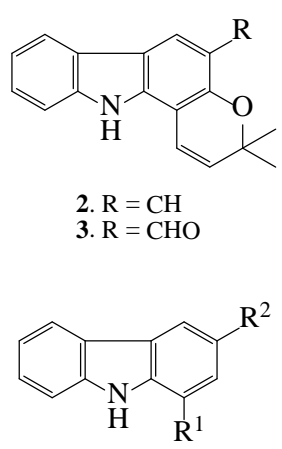

5. $\mathrm{R}^{1}=\mathrm{OCH}_{3}, \mathrm{R}^{2}=\mathrm{CHO}$

7. $\mathrm{R}^{1}=\mathrm{H}, \mathrm{R}^{2}=\mathrm{CH}_{3}$

8. $\mathrm{R}^{1}=\mathrm{OCH}_{3}, \mathrm{R}^{2}=\mathrm{CH}_{3}$

\subsection{Cytotoxic Assay}

The CEM-SS cell line (T-lymphoblastic leukimia) was obtained from the Natioanl Institutes Cancer, Frederick, Maryland, USA. The cells were cultured and maintained in growth medium as described by Ali et al. [9]. Cytotoxic test were determined by performing the microtitration assay [10]. The tests were performed in 96-well plates, a microtiter plate. Each well was added with $100 \mu \mathrm{L}$ of varying concentration of crude of Murraya koenigii and the isolated carbazoles prepared from the stock solutions by serial dilution in RPM I - 1640 medium. Subsequently, each well was filled with $100 \mu \mathrm{L}$ of cell suspension in complete growth medium at $2 \times 10^{5}$ cells $/ \mathrm{mL}$.

Controls containing only untreated cells were included for each sample. The assay for each concentration of samples were performed in triplicate and the culture plates were incubated at $37^{\circ} \mathrm{C}$ with $5 \%(\mathrm{v} / \mathrm{v}) \mathrm{CO}_{2}$ for three days. The cytotoxicity index used was $\mathrm{IC}_{50}$, which is the concentration that eields $50 \%$ inhibition of the cell compared with untreated control. Extracts or isolated compounds which exhibit cytotoxic index $\left(\mathrm{IC}_{50}\right)<20$ $\mu \mathrm{g} / \mathrm{mL}$ were considered to possess significant activity.

\subsection{Anti-Tumor Promoting Activity Assay}

\subsubsection{Treatment of Cells with Samples}

Dividing Raji cells $/ \mathrm{mL}$ in $\log$ phase at a density of $5.5 \times 10^{5}$ cells $/ \mathrm{mL}$ were incubated with $5 \mu \mathrm{L}$ plant extracts and isolated compounds at various concentrations ( 1 to $32 \mu \mathrm{g} / \mathrm{mL}$ ) in the presence of $10 \mu \mathrm{L}$ of PMA (5 $\mu \mathrm{M})$ and $6 \mu \mathrm{L}$ of sodium-n-butyrate $(0.5 \mu \mathrm{M})$. The cells were incubated for 48 hours in a ninidified incubator at $37 \mathrm{C}$ with $5 \% \mathrm{CO}_{2}$ in air. The negative controls consisted of untreated Raji cells treated with the combination of 10 $\mu \mathrm{L}$ of PMA $(5 \mu \mathrm{M})$ and $6 \mu \mathrm{L}$ of sodium-n-butyrate $(0.5 \mu \mathrm{M})$.The positive controls consisted of Raji cells treated with the combination of $10 \mu \mathrm{L}$ of PMA $(5 \mu \mathrm{M})$ and $6 \mu \mathrm{L}$ of sodium-n-butyrate $(0.5 \mu \mathrm{M})$.

\subsubsection{Epstein-Barr Virus Activation Assay}

The inhibition of Epstein-Barr virus (EBR) activation was used to evaluate in vitro antitumor promoting activity [11]. Raji cells were grown in $10 \mu \mathrm{L}$ of RPMI 1640 suplemented with $10 \%$ fetal calf serum. The cells $\left(5.5 \times 10^{5}\right.$ cells $/ \mathrm{mL}$ ) were maintained in $10 \mathrm{~mL}$ of RPMI 1640 medium suplemented witih $10 \%$ fetal calf serum containing sodium-n-butyrate $(0.5 \mu \mathrm{M})$, phorbol 12 -myristate 13 -acatate $(5 \mu \mathrm{M})$ and test extract $(5 \mu \mathrm{L})$ at $37^{\circ} \mathrm{C}$ under $5 \%$ $\mathrm{CO}_{2}$ for 48 hours using 24 wells plate. After 48 hours, the viability of cells was checked using tryphan blue dye exclusion method. Only those with viability more than $90 \%$ were used for this assay. The cells were transferred into appendorf tube and spun down at $1000 \mathrm{rpm}$ for 10 minutes by using a bench centrifuge. The supernatant the cell pellet $1 \mathrm{~mL}$ of PBS was added into wash cells and repeated twice. After the second washing, the cells were being spun down at $1000 \mathrm{rpm}$ for 10 minutes. The supernatant was removed and a drop of the cell suspension was added on to a 12 wells test Teflon coated slide (Cooke, USA).

The distribution of the cells was examined under the inverted microscope in order to make sure the drop is confluent and not over dripping. If the spread of the cells was not satisfactory, the dilution of the cells was altered. The slides with the drops of cells were dried in a laminar flow hood. The slides were then fixed in cold 
acetone for 10 minutes. Cold acetone was obtained by keeping it in $-20^{\circ} \mathrm{C}$ overnight before fixing the cells. Then, the slides were dried at room temperature and stored in slide boxed at $-20^{\circ} \mathrm{C}$ for a short period.

Antibody obtained from Nasopharryngeal carcinoma (NPC) patients was used to cover the whole well and incubated at $37^{\circ} \mathrm{C}$ for 40 minutes. To avoid drying, the cells were incubated by placing the slides on a wet tissue with cover. After 40 minutes, the slides were washed with Phosphate buffer saline (PBS) twice by dipping in PBS with gentle agitation on a platform shaker for 10 minutes each. Excess PBS was removed using tissue paper by avoiding touching the cells.

Second antibody FITC-conjugated IgG was added by covering the wells. The conjugate used in this study was anti-human IgG flourescein isothiocyanate-conjugated (FITC) (Sigma, USA). Again, the cells were incubated for 40 minutes at $37 \mathrm{C}$ by putting in a box with water. Then, excess antibody was removed by washing with PBS twice. The slides were dripped in PBS with gentle agitation on platform shaker for 10 minutes each. PBS was removed using tissue paper and avoid touching the cells. Prior checking under UV microscope, $50 \%$ glycerol was dropped on the slip (Germany). The slides were then ready for examined under fluorescent microscope.

\section{Results and Discussions}

Mahanimbine $\left(\mathbf{C}_{23} \mathbf{H}_{25} \mathbf{N O}\right)$ 1: white needles, with melting point $93^{\circ} \mathrm{C}-95^{\circ} \mathrm{C}$; $\mathrm{UV}(\mathrm{MeOH}) \lambda_{\max } 238,288 \mathrm{~nm}$; IR ( $\mathrm{KBr}$ disc) $\lambda_{\max } 3338(\mathrm{~N}-\mathrm{H}), 3312,2964,1646$ and $1156(\mathrm{C}-\mathrm{O}) \mathrm{cm}^{-1}$; GC-MS m/z $331\left(\mathrm{M}^{+}\right) .{ }^{1} \mathrm{H}$ and ${ }^{13} \mathrm{C}$ NMR see Table 1 and Table 2.

Girinimbine $\left(\mathbf{C}_{18} \mathbf{H}_{17} \mathbf{N O}\right)$ 2: colourless crystal, with melting point $171^{\circ} \mathrm{C}-173^{\circ} \mathrm{C}$; UV (MeOH) $\lambda_{\max } 237$ and $287 \mathrm{~nm}$; IR (KBr disc) $\lambda_{\max } 3338(\mathrm{~N}-\mathrm{H}), 1121(\mathrm{C}-\mathrm{O}), 742$ and $690 \mathrm{~cm}^{-1}$; GC-MS m/z $263\left(\mathrm{M}^{+}\right) .{ }^{1} \mathrm{H}$ and ${ }^{13} \mathrm{C}$ NMR see Table 1 and Table 2.

Murrayacine $\left(\mathrm{C}_{18} \mathrm{H}_{15} \mathrm{NO}_{2}\right)$ 3: greenish needles, with melting point $240^{\circ} \mathrm{C}-242^{\circ} \mathrm{C}$; UV (MeOH) $\lambda_{\max } 237$ and $288 \mathrm{~nm}$; IR (KBr disc) $\lambda_{\max } 3222(\mathrm{~N}-\mathrm{H}), 1188(\mathrm{C}-\mathrm{O})$ and $1614 \mathrm{~cm}^{-1}$; GC-MS m/z $277\left(\mathrm{M}^{+}\right) .{ }^{1} \mathrm{H}$ and ${ }^{13} \mathrm{C}$ NMR see Table 1 and Table 2.

Murrayazoline $\left(\mathbf{C}_{23} \mathbf{H}_{25} \mathbf{N O}\right)$ 4: yellow crystal, with melting point $265^{\circ} \mathrm{C}-267^{\circ} \mathrm{C}$; $\mathrm{UV}(\mathrm{MeOH}) \lambda_{\max } 235$ and $287 \mathrm{~nm}$; IR (KBr disc) $\lambda_{\max } 2936$ (C-H stretching) and 1150 (C-O) $\mathrm{cm}^{-1}$; GC-MS m/z $331\left(\mathrm{M}^{+}\right) .{ }^{1} \mathrm{H}$ and ${ }^{13} \mathrm{C}$ NMR see Table 1 and Table 2.

Murrayanine $\left(\mathrm{C}_{14} \mathbf{H}_{11} \mathbf{N O}_{2}\right)$ 5: white needles, with melting point $170^{\circ} \mathrm{C}-172^{\circ} \mathrm{C}$; UV (MeOH) $\lambda_{\max } 238,273$ and $340 \mathrm{~nm}$; IR (KBr disc) $\lambda_{\max } 3167(\mathrm{~N}-\mathrm{H})$ and $1661(\mathrm{C}=\mathrm{O})$ and $1160(\mathrm{C}-\mathrm{O}) \mathrm{cm}^{-1}$; GC-MS m/z $225\left(\mathrm{M}^{+}\right) .{ }^{1} \mathrm{H}$ and ${ }^{13} \mathrm{C}$ NMR see Table 1 and Table 2.

Mahanine $\left(\mathrm{C}_{23} \mathbf{H}_{25} \mathbf{N O}_{2}\right)$ 6: white needles, with melting point $91^{\circ} \mathrm{C}-92^{\circ} \mathrm{C}$; $\mathrm{UV}(\mathrm{MeOH}) \lambda_{\max } 235$ and $287 \mathrm{~nm}$; IR (KBr disc) $\lambda_{\max } 3417(\mathrm{NH} / \mathrm{OH})$ and $1113(\mathrm{C}-\mathrm{O}) \mathrm{cm}^{-1}$; GC-MS m/z $347\left(\mathrm{M}^{+}\right) .{ }^{1} \mathrm{H}$ and ${ }^{13} \mathrm{C}$ NMR see Table 1 and Table 2.

3-Methylcarbazole $\left(\mathbf{C}_{13} \mathbf{H}_{11} \mathbf{N}\right)$ 7: white solid, with melting point $205^{\circ} \mathrm{C}-208^{\circ} \mathrm{C}$; $\mathrm{UV}(\mathrm{MeOH}) \lambda_{\max } 235$ and $287 \mathrm{~nm}$; IR (KBr disc) $\lambda_{\max } 3407(\mathrm{NH} / \mathrm{OH})$ and $1607 \mathrm{~cm}^{-1}$; GC-MS m/z $181\left(\mathrm{M}^{+}\right) .{ }^{1} \mathrm{H}$ and ${ }^{13} \mathrm{C}$ NMR see Table 1 and Table 2.

Murrayafoline-A $\left(\mathrm{C}_{23} \mathbf{H}_{25} \mathbf{N O}_{2}\right)$ 8: dark brown viscous oil; $\mathrm{UV}(\mathrm{MeOH}) \lambda_{\max } 237$ and $287 \mathrm{~nm}$; IR (KBr disc) $\lambda_{\max } 3420(\mathrm{NH} / \mathrm{OH})$ and $1137(\mathrm{C}-\mathrm{O}) \mathrm{cm}^{-1}$; GC-MS m/z $211\left(\mathrm{M}^{+}\right) .{ }^{1} \mathrm{H}$ and ${ }^{13} \mathrm{C}$ NMR see Table 1 and Table 2.

The bark, leaves and roots of $M$. koenigii were extracted with petroluem ether, chloroform and methanol. The fractionation of the petroluem ether and chloroform extracts followed by column chromatography and TLC yield 8 carbazole alkaloids which were identified as mahanimbine $\mathbf{1}$, girinimbine $\mathbf{2}$, murrayacine $\mathbf{3}$, murrayazoline 4, murrayanine 5, mahanine 6, 3-methylcarbazole 7 and murrayafoline-A 8 by spectroscopic methods (Figure 1). All compounds have showed the similar spectroscopic features with the carbazole alkaloids published in the literature.

Crude extract of the roots and isolated compounds of M. koenigii were screened for cytotoxic activity and antitumor promoting activity. Table 3 showed the inhibition concentration $\left(\mathrm{IC}_{50}\right)$ of the tested crude extracts and isolated pure compounds that exhibited 50\% of T-lymphoblastic leukimia cells (CEM-SS) as compared to the untreated control for 72 hours. All tested samples exhibited significant cytotoxic effects towards CEM-SS cells with $\mathrm{IC}_{50}$ of $3 \mu \mathrm{g} / \mathrm{mL}$, except girinimbine, in which $\mathrm{IC}_{50}$ of $30 \mu \mathrm{g} / \mathrm{mL}$.

For the in vitro antitumor promoting activity, all crude extracts and the isolated pure compounds exhibited $100 \%$ of inhibition rate. However, most of the samples were cytotoxic towards Raji cells except girinimbine which gave $70.7 \%$ viability (Table 4 ). 
Table 1. ${ }^{1} \mathrm{H}$ NMR [500 MHz, $\left.\delta \mathrm{H}(\mathrm{J} \mathrm{Hz})\right]$ of $\mathbf{1}$ - 8 in $\mathrm{CDCl}_{3}$.

\begin{tabular}{|c|c|c|c|c|c|c|c|c|}
\hline \multirow{2}{*}{ Position } & \multicolumn{8}{|c|}{$\delta \mathrm{H}, \mathrm{J} \mathrm{Hz}$} \\
\hline & 1 & 2 & 3 & 4 & 5 & 6 & 7 & 8 \\
\hline $\mathrm{NH}$ & $7.84(\mathrm{~s})$ & $7.84(\mathrm{~s})$ & 8.14 (s) & & 8.62 & $7.74(\mathrm{~s})$ & $7.94(\mathrm{~s})$ & $8.11(\mathrm{~s})$ \\
\hline 1 & & & & & & & $\begin{array}{c}7.40 \\
(\mathrm{~d}, 7.91 \mathrm{~Hz})\end{array}$ & \\
\hline \multicolumn{9}{|l|}{$1 \mathrm{a}$} \\
\hline 2 & & & & & $7.46(\mathrm{~s})$ & & $\begin{array}{c}7.32 \\
(\mathrm{~d}, 8.41 \mathrm{~Hz})\end{array}$ & $6.68(\mathrm{~s})$ \\
\hline \multicolumn{9}{|l|}{3} \\
\hline 4 & 7.66 (s) & 7.67 (s) & $8.42(\mathrm{~s})$ & 7.48 (s) & $8.14(\mathrm{~s})$ & $7.54(\mathrm{~s})$ & $7.87(\mathrm{~s})$ & $7.45(\mathrm{~s})$ \\
\hline \multicolumn{9}{|l|}{$4 a$} \\
\hline 5 & $\begin{array}{c}7.90 \\
\text { (d, } 7.33 \mathrm{~Hz})\end{array}$ & $\begin{array}{c}7.91 \\
(\mathrm{~d}, 7.08 \mathrm{~Hz})\end{array}$ & $\begin{array}{c}7.98 \\
(\mathrm{~d}, 7.81 \mathrm{~Hz})\end{array}$ & $\begin{array}{c}7.89 \\
(\mathrm{~d}, 7.08 \mathrm{~Hz})\end{array}$ & $\begin{array}{c}8.11 \\
\text { (d, } 7.93 \mathrm{~Hz})\end{array}$ & $\begin{array}{c}7.71 \\
(\mathrm{~d}, 8.24 \mathrm{~Hz})\end{array}$ & $\begin{array}{c}8.04 \\
(\mathrm{~d}, 7.91 \mathrm{~Hz})\end{array}$ & $\begin{array}{c}7.98 \\
\text { (d, } 7.81 \mathrm{~Hz})\end{array}$ \\
\hline \multicolumn{9}{|l|}{$5 a$} \\
\hline 6 & $\begin{array}{c}7.17 \\
\text { (ddd, 8.6, } \\
7.08,0.97 \mathrm{~Hz} \text { ) }\end{array}$ & $\begin{array}{c}7.18 \\
\text { (ddd, 8.6, } \\
\text { 7.08, 0.98 Hz) }\end{array}$ & $\begin{array}{c}7.25 \\
\text { (ddd, 8.24, } \\
\text { 7.32, } 0.91 \mathrm{~Hz} \text { ) }\end{array}$ & $\begin{array}{c}7.14 \\
(\mathrm{t}, 7.45 \mathrm{~Hz})\end{array}$ & $\begin{array}{c}7.32 \\
(\mathrm{t}, 7.93 \mathrm{~Hz})\end{array}$ & $\begin{array}{c}6.67 \\
\text { (dd, } 8.24 \\
2.14 \mathrm{~Hz} \text { ) }\end{array}$ & $7.21(\mathrm{~m})$ & 7.15 (m) \\
\hline 7 & $\begin{array}{c}7.29 \\
\text { (ddd, 8.06, } \\
\text { 7.08, 0.97 Hz) }\end{array}$ & $\begin{array}{c}7.30 \\
\text { (ddd, 8.06, } \\
\text { 7.08, 0.98 Hz) }\end{array}$ & $\begin{array}{c}7.38 \\
\text { (ddd, 8.45, } \\
7.32,1.22 \mathrm{~Hz} \text { ) }\end{array}$ & $\begin{array}{c}7.24 \\
(\mathrm{t}, 7.08 \mathrm{~Hz})\end{array}$ & $\begin{array}{c}7.51 \\
\text { (t, } 8.24 \mathrm{~Hz})\end{array}$ & & $7.21(\mathrm{~m})$ & 7.15 (m) \\
\hline 8 & $\begin{array}{c}7.36 \\
(\mathrm{~d}, 7.81 \mathrm{~Hz})\end{array}$ & $\begin{array}{c}7.36 \\
(\mathrm{~d}, 8.06 \mathrm{~Hz})\end{array}$ & $\begin{array}{c}7.39 \\
(\mathrm{~d}, 7.08 \mathrm{~Hz})\end{array}$ & $\begin{array}{c}7.46 \\
(\mathrm{~d}, 10.50 \mathrm{~Hz})\end{array}$ & $\begin{array}{c}7.49 \\
(\mathrm{~d}, 7.93 \mathrm{~Hz})\end{array}$ & $\begin{array}{c}6.83 \\
\text { (d, } 2.14 \mathrm{~Hz})\end{array}$ & $\begin{array}{c}7.40 \\
(\mathrm{~d}, 7.91 \mathrm{~Hz})\end{array}$ & $\begin{array}{c}7.31 \\
\text { (d, } 6.35 \mathrm{~Hz})\end{array}$ \\
\hline \multicolumn{9}{|l|}{$8 a$} \\
\hline 9 & $\begin{array}{c}6.63 \\
\text { (d, } 9.76 \mathrm{~Hz})\end{array}$ & $\begin{array}{c}6.61 \\
\text { (d, } 9.77 \mathrm{~Hz})\end{array}$ & $\begin{array}{c}6.63 \\
(\mathrm{~d}, 9.77 \mathrm{~Hz})\end{array}$ & $\begin{array}{c}3.30 \\
\text { (d, } 4.64 \mathrm{~Hz})\end{array}$ & & $\begin{array}{c}6.61 \\
\text { (d, } 10.00 \mathrm{~Hz})\end{array}$ & & \\
\hline 10 & $\begin{array}{c}5.65 \\
(\mathrm{~d}, 9.76 \mathrm{~Hz})\end{array}$ & $\begin{array}{c}5.69 \\
(\mathrm{~d}, 9.77 \mathrm{~Hz})\end{array}$ & $\begin{array}{c}5.80 \\
(\mathrm{~d}, 9.77 \mathrm{~Hz})\end{array}$ & 1.45 (m) & & $\begin{array}{c}5.65 \\
(\mathrm{~d}, 10.00 \mathrm{~Hz})\end{array}$ & & \\
\hline \multicolumn{9}{|l|}{11} \\
\hline 11-Me' & 1.45 (s) & $1.48(\mathrm{~s})$ & $1.56(\mathrm{~s})$ & $1.28(\mathrm{~s})$ & & $1.43(\mathrm{~s})$ & & \\
\hline 11-Me" & & $1.48(\mathrm{~s})$ & $1.56(\mathrm{~s})$ & & & & & \\
\hline 3-Me & $2.33(\mathrm{~s})$ & $2.33(\mathrm{~s})$ & & $2.32(\mathrm{~s})$ & & $2.31(\mathrm{~s})$ & $2.53(\mathrm{~s})$ & $2.49(\mathrm{~s})$ \\
\hline 3-CHO & & & $10.50(\mathrm{~s})$ & & 10.05 (s) & & & \\
\hline 1-OMe & & & & & $4.06(\mathrm{~s})$ & & & 3.89 (s) \\
\hline $1^{\prime}$ & $\begin{array}{c}1.76 \\
\text { (t, } 8.42 \mathrm{~Hz})\end{array}$ & & & $1.45(\mathrm{~m})$ & & $\begin{array}{c}1.75 \\
\text { (t, } 8.39 \mathrm{~Hz})\end{array}$ & & \\
\hline $2^{\prime}$ & $2.15(\mathrm{~m})$ & & & $1.45(\mathrm{~m})$ & & $2.16(\mathrm{~m})$ & & \\
\hline $3^{\prime}$ & $\begin{array}{c}5.11 \\
(\mathrm{t}, 7.20 \mathrm{~Hz})\end{array}$ & & & $1.45(\mathrm{~m})$ & & $\begin{array}{c}5.11 \\
(\mathrm{t}, 7.17 \mathrm{~Hz})\end{array}$ & & \\
\hline \multicolumn{9}{|l|}{$4^{\prime}$} \\
\hline $5^{\prime}$ & $1.58(\mathrm{~s})$ & & & & & 1.54 (s) & & \\
\hline $6^{\prime}$ & 1.65 (s) & & & & & 1.65 (s) & & \\
\hline 4'-Me' & & & & $1.90(\mathrm{~s})$ & & & & \\
\hline 4'-Me" & & & & 1.90 (s) & & & & \\
\hline 7-OH & & & & & & $4.70(\mathrm{~s})$ & & \\
\hline
\end{tabular}


Table $2 .{ }^{13} \mathrm{C}$ NMR $[125 \mathrm{MHz}, \delta \mathrm{C}(\mathrm{J} \mathrm{Hz})]$ of $\mathbf{1}-\mathbf{8}$ in $\mathrm{CDCl}_{3}$.

\begin{tabular}{|c|c|c|c|c|c|c|c|c|}
\hline \multirow{2}{*}{ Position } & \multicolumn{8}{|c|}{$\delta \mathrm{C}$} \\
\hline & 1 & 2 & 3 & 4 & 5 & 6 & 7 & 8 \\
\hline 1 & 104.2 & 104.4 & 103.6 & 107.3 & 146.1 & 104.2 & 127.1 & 145.3 \\
\hline $1 \mathrm{a}$ & 138.4 & 139.4 & 139.7 & 142.4 & 139.4 & 140.7 & 139.8 & 129.4 \\
\hline 2 & 149.9 & 149.8 & 154.3 & 155.0 & 103.5 & 149.0 & 119.2 & 107.6 \\
\hline 3 & 116.6 & 116.7 & 117.7 & 113.9 & 130.2 & 116.7 & 123.2 & 127.9 \\
\hline 4 & 121.2 & 121.1 & 119.4 & 113.4 & 120.4 & 120.4 & 120.2 & 112.5 \\
\hline $4 a$ & 118.4 & 118.6 & 118.6 & 118.4 & 123.6 & 118.2 & 123.5 & 123.4 \\
\hline 5 & 119.4 & 119.5 & 119.8 & 119.8 & 120.7 & 120.0 & 120.2 & 120.4 \\
\hline $5 a$ & 123.9 & 123.9 & 123.6 & 127.3 & 123.6 & 118.3 & 128.7 & 124.3 \\
\hline 6 & 119.3 & 119.3 & 120.5 & 119.2 & 120.7 & 117.5 & 110.2 & 119.0 \\
\hline 7 & 124.2 & 124.2 & 125.5 & 122.6 & 111.5 & 153.5 & 125.6 & 110.9 \\
\hline 8 & 110.3 & 110.4 & 110.2 & 119.1 & 126.6 & 96.9 & 110.5 & 125.4 \\
\hline $8 a$ & 134.8 & 134.8 & 139.6 & 140.6 & 134.0 & 134.7 & 137.7 & 139.4 \\
\hline 9 & 117.5 & 117.2 & 115.6 & 29.2 & & 108.3 & & \\
\hline 10 & 128.5 & 129.4 & 129.6 & 28.3 & & 128.7 & & \\
\hline 11 & 78.1 & 75.8 & 76.2 & 76.1 & & 78.0 & & \\
\hline 11-Me' & 25.8 & 27.6 & 27.5 & 22.9 & & 25.8 & & \\
\hline 11-Me" & & 27.6 & 27.5 & & & & & \\
\hline 3-Me & 16.1 & 16.1 & & 15.4 & & 16.0 & 21.4 & 21.9 \\
\hline 3-СHO & & & 188.7 & & 191.8 & & & \\
\hline 1-OMe & & & & & 55.8 & & & 55.4 \\
\hline $1^{\prime}$ & 40.7 & & & 48.6 & & 40.7 & & \\
\hline $2^{\prime}$ & 22.7 & & & 36.1 & & 22.7 & & \\
\hline $3^{\prime}$ & 124.1 & & & 21.8 & & 124.2 & & \\
\hline $4^{\prime}$ & 131.7 & & & 60.4 & & 131.6 & & \\
\hline $5^{\prime}$ & 17.6 & & & & & 17.6 & & \\
\hline $6^{\prime}$ & 25.7 & & & & & 25.6 & & \\
\hline 4'-Me' & & & & 30.1 & & & & \\
\hline 4'-Me" & & & & 36.8 & & & & \\
\hline
\end{tabular}



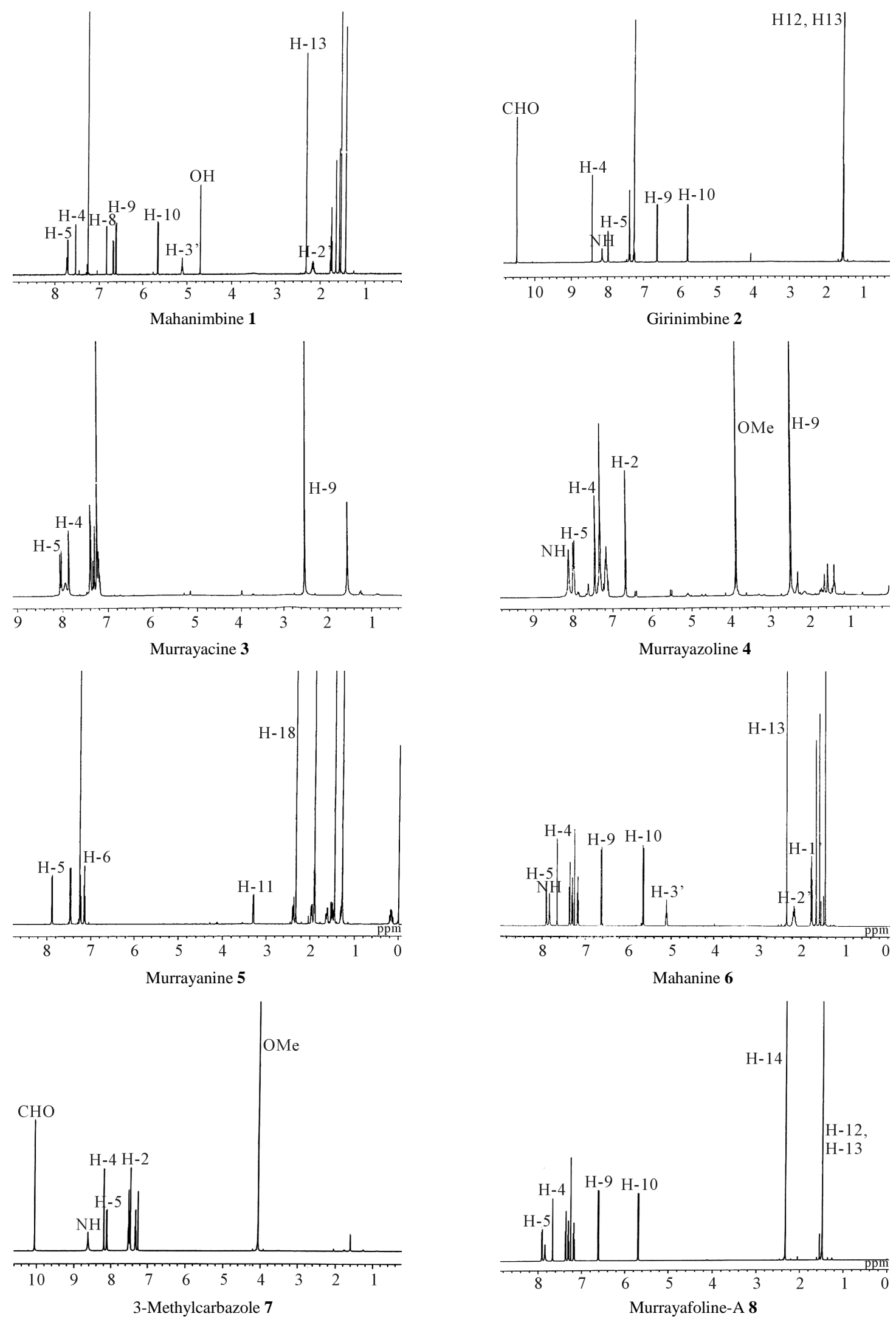

Figure 1. ${ }^{1} \mathrm{H}$ NMR Spectra of $\mathbf{1}$ - 8 . 
Table 3. Cytotoxic activity of crude extracts and isolated pure compounds from the roots of $M$. koenigii on CEM-SS cell line.

\begin{tabular}{cc}
\hline Samples & $\mathrm{IC}_{50}(\mu \mathrm{g} / \mathrm{mL})$ \\
\hline Petroluem ether crude & 3 \\
Chloroform crude & 3 \\
Methanol crude & 3 \\
Mahanimbine $\mathbf{1}$ & 3 \\
Girinimbine $\mathbf{2}$ & 30 \\
Mahanine 6 & 3 \\
Murrayafoline-A 8 & 3 \\
\hline
\end{tabular}

Table 4. In vitro antitumor promoting activity and Raji cell viability.

\begin{tabular}{ccc}
\hline Samples & Viability (\%) & Inhibition Rate (\%) \\
\hline Petroluem ether crude & 2.4 & 100 \\
Chloroform crude & 0 & 100 \\
Methanol crude & 2.2 & 100 \\
Mahanimbine $\mathbf{1}$ & 0 & 100 \\
Girinimbine 2 & 70.7 & 100 \\
Mahanine 6 & 0.7 & 100 \\
Murrayafoline-A 8 & 0 & 100 \\
\hline
\end{tabular}

\section{Acknowledgements}

We gratefully acknowledge the technical support provided by University Pendidikan Sultan Idris and University Putra Malaysia.

\section{References}

[1] Gupta, P., Nahata, A. and Dixit, V.K. (2011) An Update on Murraya koenigii Spreng: A Multifunctional Ayurvedic herb. Journal of Chinese Integrative Medicine, 9, 824-833. http://dx.doi.org/10.3736/jcim20110803

[2] Sukari, M.A., Ahmad, K., Haron, M.J. and Muse, R. (2001) Carbazole Alkaloids from the Roots of Murraya koenigii (Rutaceae). Malaysian Journal of Analytical Sciences, 7, 263-265.

[3] Abu Bakar, N.H., Sukari, M.A., Rahmani, M., Sharif, A.M., Khalid, K., et al. (2007) Chemical Constituents from Stem Bark and Roots of Murraya koenigii (Rutaceae). The Malaysian Journal of Analytical Sciences, 11, 173-176.

[4] Tachibana, Y., Kikuzaki, H., Lajis, N.H. and Nakatani, N. (2003) Comparison of Antioxidative Properties of Carbazole Alkaloids from Murraya koenigii Leaves. Journal of agricultural and food chemistry, 51, 6461-6467. http://dx.doi.org/10.1021/jf034700+

[5] Ajay, S., Rahul, S., Sumit, G., Paras, M., Mishra, A., et al. (2011) Comprehensive Review: Murraya koenigii Linn. Asian Journal of Pharmacy and Life Science, 1, 417-425.

[6] Adebajo, A.C., Ayoola, O.F., Iwalewa, E.O., Akindahunsi, A.A., Omisore, N.O.A., et al. (2006) Anti-Trichomonal, Biochemical and Toxicological Activities of Methanolic Extract and Some Carbazole Alkaloids Isolated from the Leaves of Murraya koenigii Growing in Nigeria. Phytomedicine, 13, 246-254. http://dx.doi.org/10.1016/j.phymed.2004.12.002

[7] Ramsewak, R., Nair, M.G., Strasburg, G.M., DeWitt, D.L. and Nitiss, J.L. (1999) Biologically Active Carbazole Alkaloids from Murraya koenigii. Journal of Agricultural and Food Chemistry, 47, 444-447. http://dx.doi.org/10.1021/jf9805808

[8] Tachibana, Y., Kikuzaki, H., Lajis, N.H. and Nakatani, N. (2001) Antioxidative Activity of Carbazoles from Murraya 
koenigii Leaves. Journal of agricultural and food chemistry, 49, 5589-5594. http://dx.doi.org/10.1021/jf010621r

[9] Ali, A.M., Mackeen, M.M., Safinar, I., Hamid, I., Lajis, N.H., et al. (1996) Antitumor Promoting and Antitumor Activities of the Crude Extract from the Leaves of Juniperus chinensis. Journal of Ethnopharmacology, 53, 165-169. http://dx.doi.org/10.1016/0378-8741(96)01434-1

[10] Shier, W.T. (1983) An Undergraduate Experiment to Demonstrate the Use of Cytotoxic Drugs in Cancer Chemotherapy. American Journal of Pharmaceutical Education, 47, 216-220.

[11] Ohigashi, H., Takamura, H., Koshimizu, K., Takuda, H. and Ito, Y. (1986) Search for Possible Antitumor Promoters by Inhibition of 12-O-Tetradeconoylphorbo-13-Acetate Induced Epstein-Barr Virus Activation; Ursolic Acid and Oleanolic Acid from an Anti-Inflammatory Chinese Medicinal Plant, Glechoma hederaceae L. Cancer Letter, 30, 143-145. http://dx.doi.org/10.1016/0304-3835(86)90082-0 
Scientific Research Publishing (SCIRP) is one of the largest Open Access journal publishers. It is currently publishing more than 200 open access, online, peer-reviewed journals covering a wide range of academic disciplines. SCIRP serves the worldwide academic communities and contributes to the progress and application of science with its publication.

Other selected journals from SCIRP are listed as below. Submit your manuscript to us via either submit@scirp.org or Online Submission Portal.
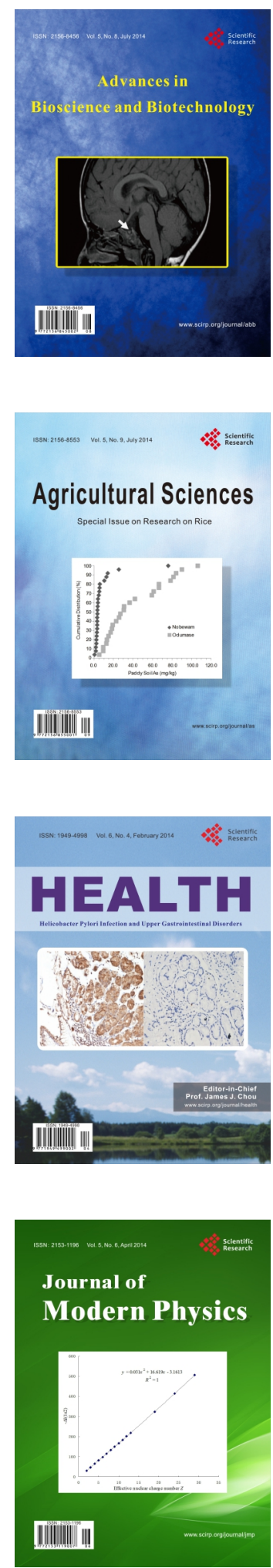
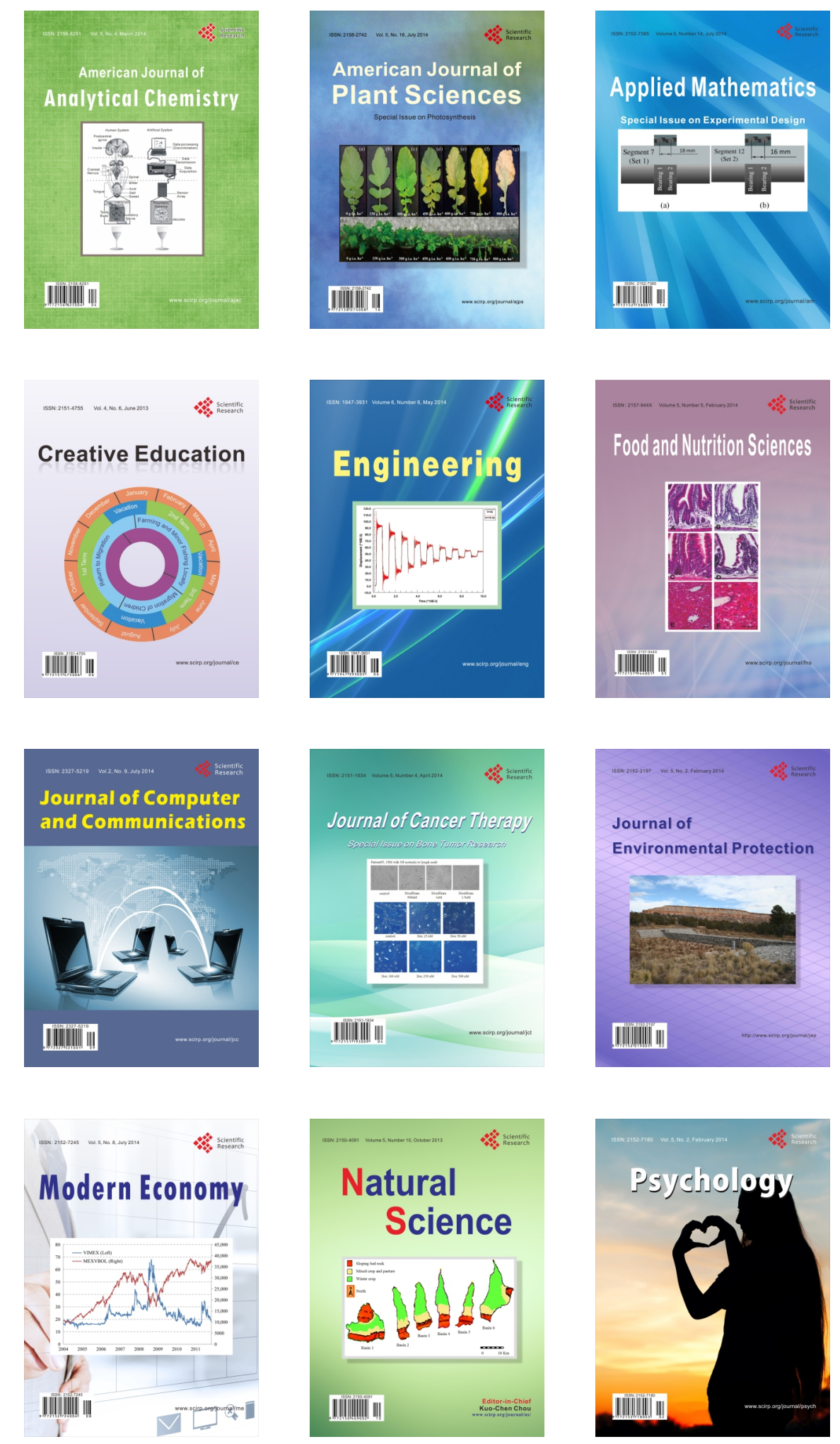